\title{
Biofiltration of methane: effect of temperature and nutrient solution
}

\author{
C. Menard, A. Avalos Ramirez, J. Nikiema \& M. Heitz \\ Department of Chemical Engineering and Biotechnological Engineering, \\ Université de Sherbrooke, Canada
}

\begin{abstract}
Methane is a greenhouse gas (GHG) 21 times more contributing to global warming than carbon dioxide $\left(\mathrm{CO}_{2}\right)$ and originates mainly from the energy, agriculture and landfill sectors. Methane can be valorized via combustion or transformed by catalytic processes into products like methanol. When valorization cannot be applied because of inappropriate flow rates or methane concentrations, biofiltration is a biotechnology well adapted to control the methane emissions. Biofiltration is a triphasic biotechnology, which uses microorganisms to reduce pollutants like volatile organic compounds (VOCs) or volatile inorganic compounds (VICs) or GHG like methane. Several studies have been published over the last three decades about VOC and VIC biofiltration, but fewer studies are available about methane control.

At the Université de Sherbrooke, research is being conducted to control methane emissions originating from landfills or livestock productions. The biofilter used in this study is a laboratory-scale bioreactor of $0.018 \mathrm{~m}^{3}$ divided into 3 sections. An inorganic packing material is used as the filter bed and a nutrient solution is supplied to irrigate the biofilter once daily.

The objective of the present study is to determine the operating conditions to obtain high removal efficiencies at methane inlet concentrations around $7000 \mathrm{ppmv}$. The biofilter is operated under a nitrogen concentration of $0.5 \mathrm{gN} / \mathrm{L}$ and an inlet flow rate of air/methane mixture of $0.25 \mathrm{~m}^{3} / \mathrm{h}$. The parameters tested are the temperature of the bed filter and the amount of nutrient solution supplied to the biofilter. Better performances are obtained in the temperature range of $28-30^{\circ} \mathrm{C}$ with an elimination capacity of $39 \mathrm{gCH}_{4} / \mathrm{m}^{3} / \mathrm{h}$ for an inlet load of $67 \mathrm{gCH}_{4} / \mathrm{m}^{3} / \mathrm{h}$. Reducing the daily amount of nutrient solution from 1500 to $250 \mathrm{ml} / \mathrm{d}$ affects the biofilter as it provokes a clogging phenomenon. The best
\end{abstract}


performance is obtained with a minimal amount of nutrient solution of $1000 \mathrm{ml} / \mathrm{d}$ with an elimination capacity of $33 \mathrm{gCH}_{4} / \mathrm{m}^{3} / \mathrm{h}$ for an inlet load of $78 \mathrm{gCH}_{4} / \mathrm{m}^{3} / \mathrm{h}$.

Keywords: biofiltration, methane, temperature, nutrient solution, air pollution, environment.

\section{Introduction}

Landfills contribute to global warming due to methane $\left(\mathrm{CH}_{4}\right)$ emissions. Landfills were responsible for $3.7 \%$ of the global emissions of greenhouse gas in Canada in 2005 [1]. Among the various sources of anthropogenic $\mathrm{CH}_{4}$ production, waste elimination represented $24 \%$ of the emissions. Biogas from landfills can be either valorized or eliminated. Energetic valorization is advantageous as it provides both electricity and heat. However, it requires high $\mathrm{CH}_{4}$ concentration, above $30-40 \%$ (v/v) to be efficient [2], which is reachable only during the first decades of landfill activity. Then, landfill emissions decrease but low emissions still occur up to several years. Biological $\mathrm{CH}_{4}$ oxidation is a more adequate treatment for landfill with lower gas emissions $(<20 \% \mathrm{v} / \mathrm{v})$ [2], [3]. Biofiltration is a biotechnology, which uses microorganisms to transform pollutants like $\mathrm{CH}_{4}$ into water, $\mathrm{CO}_{2}$, biomass and salts. A nutrient solution containing the main macro and micro nutrients $(\mathrm{N}, \mathrm{P}, \ldots)$, necessary to the microorganisms is periodically supplied to the biofilter. Several factors must be optimized to improve $\mathrm{CH}_{4}$ oxidation during biofiltration [4]. As an example, temperature and nutrient supply are among the important parameters to ensure an optimal microbial growth.

The main objective of the present study is to determine the operating conditions in terms of temperature and nutrient solution amount for high removal efficiencies at a $\mathrm{CH}_{4}$ concentration of $7000 \mathrm{ppmv}$ and a flow rate of $0.25 \mathrm{~m}^{3} / \mathrm{h}$.

\section{Materials and methods}

\subsection{Experimental set-up}

The experimental set-up is shown in Figure 1. The upflow laboratory-scale biofilter column is made of Plexiglas with an internal diameter of $0.15 \mathrm{~m}$. The biofilter is divided into 3 identical sections of $0.33 \mathrm{~m}$ high and filled with an inorganic medium. Due to an existing confidentiality agreement, specific details about the characteristics of the medium are not available for publication at this time. The gas mixture is carried out at the bottom of the biofilter and consisted in mixing a pre-humidified air and pure methane (Praxair Inc., Québec) in the desired concentrations. The gas exit is sent to an evacuation system.

\subsection{Operating conditions}

Experiments were carried out on 2 biofilters to evaluate the influence of temperature (BF1) and the amount of nutrient solution supplied (BF2). The 2 biofilters were operated under the same inlet air flow rate of $0.25 \mathrm{~m}^{3} / \mathrm{h}$ and at a 


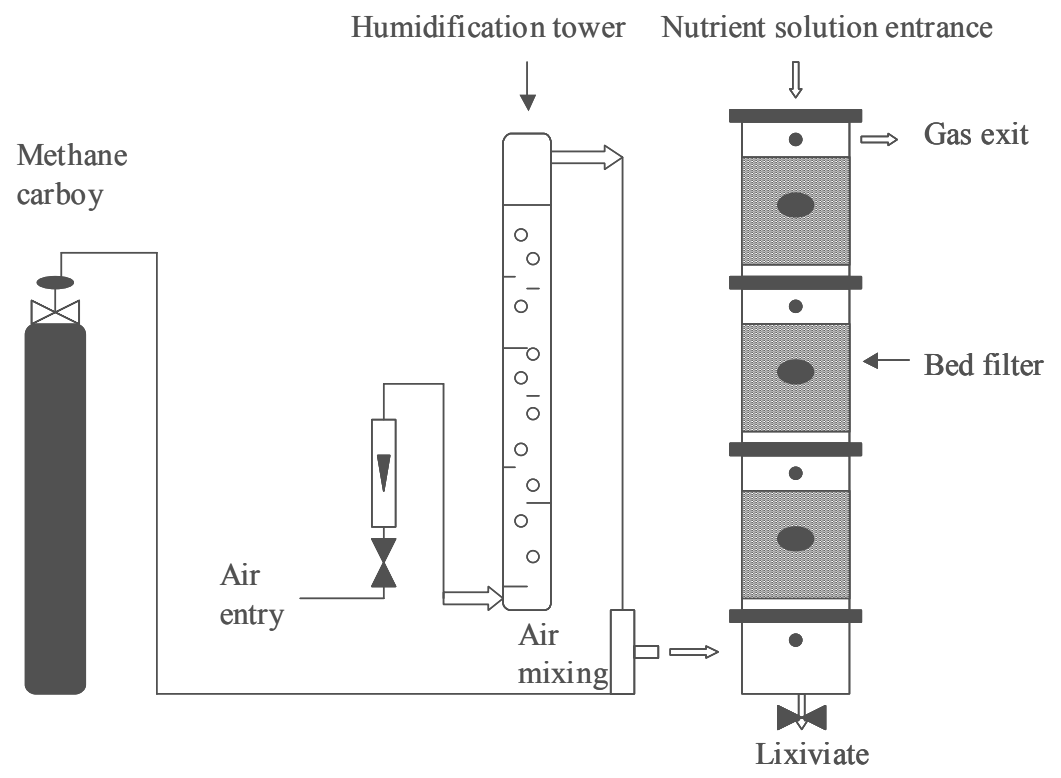

Figure 1: Laboratory-scale biofiltration system.

methane concentration around 7000-7500 ppmv. The inlet load (IL) was around $67 \mathrm{gCH}_{4} / \mathrm{m}^{3} / \mathrm{h}$ for BF1 and $78 \mathrm{gCH}_{4} / \mathrm{m}^{3} / \mathrm{h}$ for BF2. The nitrogen concentration was $0.5 \mathrm{~g} / \mathrm{L}$.

BF1 was supplied with $1000 \mathrm{ml} / \mathrm{d}$ of nutrient solution (NS), and temperatures inside the biofilter were varied from 24 to $33^{\circ} \mathrm{C}$ with a silicon heating blanket. $\mathrm{BF} 2$ was operated under the ambient temperature $\left(22-24^{\circ} \mathrm{C}\right)$ during all the experiments. Amount of NS ranged from 250 to $1500 \mathrm{ml} / \mathrm{d}$.

\subsection{Nutrient solution composition}

Biofilters were supplied every day with the NS. The detailed composition of NS for the macronutrients is described in the Table 1. The detailed composition for the micronutrients is presented elsewhere [5].

Table 1: Composition of the macronutrient solution.

\begin{tabular}{cc}
\hline Nutrients & Concentration $(\mathrm{mg} / \mathrm{L})$ \\
\hline $\mathrm{NaNO}_{3}$ & 3038 \\
$\mathrm{~K}_{2} \mathrm{SO}_{4}$ & 170 \\
$\mathrm{MgSO}_{4}, 7 \mathrm{H}_{2} \mathrm{O}$ & 37 \\
$\mathrm{CaCl}_{2}, 2 \mathrm{H}_{2} \mathrm{O}$ & 7 \\
$\mathrm{KH}_{2} \mathrm{PO}_{4}$ & 530 \\
$\mathrm{Na}_{2} \mathrm{HPO}_{4}$ & 860 \\
\hline
\end{tabular}




\subsection{Parameters for analyzing biofilter performance}

Performance of biofiltration is expressed according to the following parameters:

$$
\begin{gathered}
\mathrm{IL}=\frac{C_{i}^{*} Q}{V_{\text {bed }}} \\
\mathrm{EC}=\frac{\left(C_{i}-C_{o}\right) * Q}{V_{\text {bed }}} \\
\mathrm{X}=\frac{C_{i}-C_{o}}{C_{i}} \\
Y_{\text {Biomass } / C H_{4}}=\frac{\Delta\left(m_{B}\right)}{\Delta(T)^{*} V_{\text {bed }} * E C}
\end{gathered}
$$

where IL is the inlet load $\left(\mathrm{g} / \mathrm{m}^{3} / \mathrm{h}\right)$, EC is the elimination capacity $\left(\mathrm{g} / \mathrm{m}^{3} / \mathrm{h}\right), \mathrm{X}$ is the removal efficiency (dimensionless), $\mathrm{Y}_{\mathrm{Biomas} / \mathrm{CH}_{4}}$ is the biomass yield coefficient (gBiomass produced $/ \mathrm{gCH}_{4 \text { consummed }}$ ), Q is the total air flow rate $\left(\mathrm{m}^{3} / \mathrm{h}\right)$, $\mathrm{V}_{\text {bed }}$ is the packing bed volume $\left(\mathrm{m}^{3}\right), \mathrm{C}_{\mathrm{i}}$ is the methane inlet concentration $\left(\mathrm{g} / \mathrm{m}^{3}\right)$, $\mathrm{C}_{\mathrm{o}}$ is the methane outlet concentration $\left(\mathrm{g} / \mathrm{m}^{3}\right), \Delta\left(\mathrm{m}_{\mathrm{B}}\right)$ is the dry biomass weight and $\Delta(\mathrm{T})$ is the delay time between each measure.

The inlet and outlet concentrations of methane present in the gas phase were measured by means of a total hydrocarbon analyzer Horiba FIA-510 (Horiba, USA). Bed pressure drop was measured with a differential manometer (Air Flow Developments Ltd, UK, Type 4).

\section{Results and discussion}

\subsection{Influence of temperature}

For each range of temperature tested, the inlet load (IL) and the elimination capacity (EC) are presented in Figure 2.

Range 1 was operated under ambient temperature, the temperatures measured inside the biofilter varied from $25^{\circ} \mathrm{C}$ in the bottom section to $26^{\circ} \mathrm{C}$ in both the middle and top section. In range 2 , the biofilter was insulated with an aluminium blanket. An increased of $1.2^{\circ} \mathrm{C}$ was noticed in each section compared to range 1 . Ranges 3 and 4 were obtained due to the heating blanket and the temperatures inside the biofilter reached $28-30^{\circ} \mathrm{C}$ and $30-33^{\circ} \mathrm{C}$ respectively.

For range 1, EC averaged $32 \pm 2 \mathrm{gCH}_{4} / \mathrm{m}^{3} / \mathrm{h}$. In range 2, performance of biofilter remained similar to range 1. For range 3, EC reached $39 \pm 2 \mathrm{gCH}_{4} / \mathrm{m}^{3} / \mathrm{h}$ during 10 days. Then, it decreased to $33 \mathrm{gCH}_{4} / \mathrm{m}^{3} / \mathrm{h}$. In range 4 , EC averaged $34 \pm 2 \mathrm{gCH}_{4} / \mathrm{m}^{3} / \mathrm{h}$. 


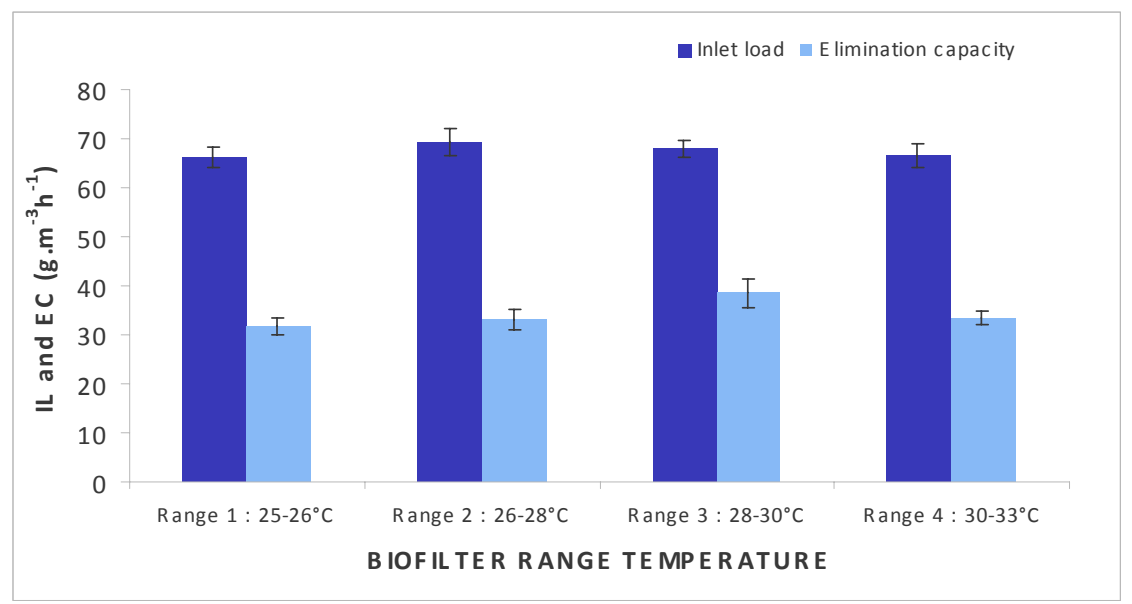

Figure 2: Inlet load and elimination capacity as a function of biofilter range temperature (BF1).

Heating increased the biofilter EC when the temperatures ranged $28-30^{\circ} \mathrm{C}$ (range 3), which is coherent with the optimal range $\left(25-36^{\circ} \mathrm{C}\right)$ found in the literature for some landfill soils [6], [7]. However, after 3 weeks of heating, EC decreased and reached the same value as it was when the biofilter was operated without insulation (Range 1).

The biofiltration under ambient temperature was sufficient to provide a methane conversion of $50 \%$.

\subsection{Influence of nutrient solution amount supplied}

Figure 3 presents the inlet load and the elimination capacity as a function of NS amount supplied. The different amounts of NS, from 1500 to $250 \mathrm{ml} / \mathrm{d}$, did not strongly influence EC which decreased from 33 to $27.5 \mathrm{gCH}_{4} / \mathrm{m}^{3} / \mathrm{h}$. However, visual observations led to notice a clogging phenomenon in the top section when reducing the NS amount supplied. The measured pressure drop gave a value of $0.20 \mathrm{~cm} \mathrm{H}_{2} \mathrm{O} / \mathrm{m}$ between the bottom and the top section, which was 20 times higher than the one observed for $\mathrm{BF} 1\left(0.01 \mathrm{~cm} \mathrm{H}_{2} \mathrm{O} / \mathrm{m}\right)$. The pressure drop decreased to $0.10 \mathrm{~cm} \mathrm{H}_{2} \mathrm{O} / \mathrm{m}$ after supplying $1500 \mathrm{ml} / \mathrm{d}$ for 3 weeks. The "high" pressure drop observed when NS supplied decreased could be explained by the fact that the top section was favourable to a strong biomass growth thanks to the uptake of all nutrients. Due to the consumption of nutrients by the top section, the bottom and middle sections were deprived of such nutrients.

These observations could be linked to the biomass yield coefficient

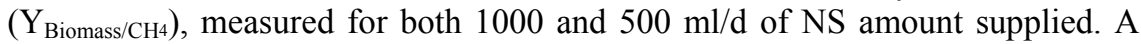
higher value was obtained for $500 \mathrm{ml} / \mathrm{d}$ with 0.13 gbiomass $/ \mathrm{gCH}_{4}$ while it was only 0.05 gbiomass $/ \mathrm{gCH}_{4}$ for $1000 \mathrm{ml} / \mathrm{d}$. 


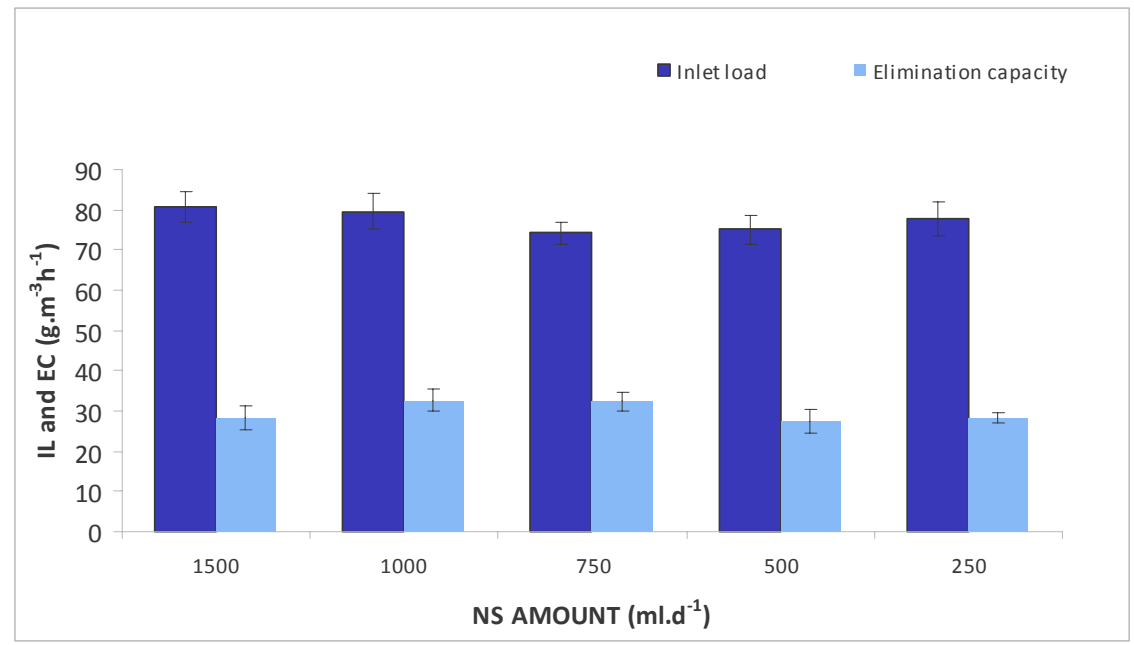

Figure 3: Inlet load and elimination capacity as a function of NS amount supplied (BF2).

To homogenize methane oxidation in the biofilter, it is important to provide enough nutrients to each section. NS amount supplied should remain around $1000 \mathrm{ml} / \mathrm{d}$ to avoid clogging phenomenon. However, it is not necessary to provide more than $1000 \mathrm{ml} / \mathrm{d}$ to minimize lixiviate production.

\section{Conclusions}

The main objective of this study was to optimize 2 parameters of methane biofiltration, the temperature and the amount of nutrient solution supplied everyday, to obtain high conversion. Four ranges of temperature, between 24 and $33^{\circ} \mathrm{C}$, were tested. No optimal range was found; $50 \%$ of conversion was obtained during the biofiltration under ambient temperature. More experiments would be needed with temperatures lower than $20^{\circ} \mathrm{C}$ to conclude about an optimal temperature. Reducing the amount of NS from 1500 to $250 \mathrm{ml} / \mathrm{d}$ did not affect methane oxidation directly but provoked a clogging phenomenon into the biofilter. It is to be noted that one needs to avoid pressure drop to ensure less operating maintenance and energy loss in a case of an industrial application. Optimal range of daily amount NS supplied should remain around $1000 \mathrm{ml}$.

\section{Acknowledgements}

The authors are indebted to the Natural Science and Engineering Research Council of Canada (NSERC) for the financial support to this project. The authors are also thankful to B. Sharma Gukhool (Graduate Student at the Université de Sherbrooke) for English text revision. 


\section{References}

[1] Environnement Canada, Rapport d'inventaire national 1990-2005 : Sources et puits de gaz à effet de serre au Canada. ISBN : 978-0-662-07181-5, 2007 (www.ec.gc.ca/ghg-ges).

[2] Haubrichs, R., \& Widmann, R., Evaluation of aerated biofilter systems for microbial methane oxidation of poor landfill gas. Waste Management, 26(4), pp. 408-416, 2006.

[3] Huber-Humer, M., Gebert J., \& Hilger H., Biotic systems to mitigate landfill methane emissions. Waste Management \& Research 26(1): pp.33-46, 2008.

[4] Hanson, R., \& Hanson, T., Methanotrophic bacteria. Microbiological Reviews, 60(2), pp. 439-471, 1996.

[5] Nikiema, J., \& Heitz, M., The influence of the gas flow rate during methane biofiltration on an inorganic packing material. Canadian Journal of Chemical Engineering, 87(1), pp. 136-142, 2009.

[6] Visvanathan, C., Pokhrel, D., Cheimchaisri, W., Hettiaratchi, J. P. A., \& Wu J. S., Methanotrophic activities in tropical landfill cover soils: effects of temperature, moisture content and methane concentration. Waste Management \& Research, 17(4), pp. 313-323, 1999.

[7] Park, S., Lee C. H., Ryu C. R., \& Sung K., Biofiltration for reducing methane emissions from modern sanitary landfills at the low methane generation stage. Water Air and Soil Pollution, 196, pp. 19-27, 2009. 